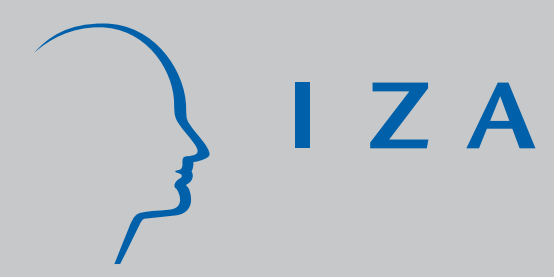

IZA DP No. 1836

Youth Emancipation and Perceived J ob Insecurity of Parents and Children

Sascha O. Becker

Samuel Bentolila

Ana Fernandes

Andrea Ichino

November 2005 


\title{
Youth Emancipation and Perceived Job Insecurity of Parents and Children
}

\author{
Sascha O. Becker \\ CES, CESifo and IZA Bonn
}

\author{
Samuel Bentolila
}

CEMFI, CEPR and CESifo

\author{
Ana Fernandes \\ University of Bern
}

Andrea Ichino

EUI, CEPR, CESifo and IZA Bonn

Discussion Paper No. 1836

November 2005

\author{
IZA \\ P.O. Box 7240 \\ 53072 Bonn \\ Germany \\ Phone: +49-228-3894-0 \\ Fax: +49-228-3894-180 \\ Email: iza@iza.org
}

\begin{abstract}
Any opinions expressed here are those of the author(s) and not those of the institute. Research disseminated by IZA may include views on policy, but the institute itself takes no institutional policy positions.

The Institute for the Study of Labor (IZA) in Bonn is a local and virtual international research center and a place of communication between science, politics and business. IZA is an independent nonprofit company supported by Deutsche Post World Net. The center is associated with the University of Bonn and offers a stimulating research environment through its research networks, research support, and visitors and doctoral programs. IZA engages in (i) original and internationally competitive research in all fields of labor economics, (ii) development of policy concepts, and (iii) dissemination of research results and concepts to the interested public.
\end{abstract}

IZA Discussion Papers often represent preliminary work and are circulated to encourage discussion. Citation of such a paper should account for its provisional character. A revised version may be available directly from the author. 
IZA Discussion Paper No. 1836

November 2005

\section{ABSTRACT \\ Youth Emancipation and Perceived Job Insecurity of Parents and Children}

The age at which children leave the parental home differs considerably across countries. In this paper we argue that lower job insecurity of parents and higher job insecurity of children delay emancipation. We provide aggregate evidence which supports this hypothesis for 12 European countries and which helps account for the increase in coresidence in the 1990s. We also give microeconometric evidence for Italy, a country for which we have access to household-specific information on job security of fathers and coresidence. In the late 1990s, approximately $75 \%$ of young Italians aged 18 to 35 were living at home and they had only a $4 \%$ probability of emancipation in the 3 subsequent years. We show that this probability would have increased by 4 to 10 percentage points if their fathers had gone from perceiving to have a fully secure job to expecting to be unemployed for sure.

JEL Classification: $\quad \mathrm{J} 1, \mathrm{~J} 2$

Keywords: coresidence, youth emancipation, job security

Corresponding author:

Andrea Ichino

European University Institute

Department of Economics

Via Piazzuola 43

I-50133 Firenze

Italy

Email: andrea.ichino@iue.it

\footnotetext{
This research is supported by the European Commission TSER Project number ERB4142 PL97/3148. We thank the comments of Gian Luca Clementi, Sandra Black, Randy Wright, and seminar participants at the CEP (LSE), CEPR TSER workshop on "Labor Demand, Education and the Dynamics of Social Exclusion" (June 2001), EALE 14th Annual Congress, EEA 17th and 18th Annual Congresses, ESSLE 2002, IZA, SED 2003, and the Universities of Frankfurt, Mannheim, Munich, Oxford, Pompeu Fabra, Salamanca, and Salerno. We also thank Luigi Guiso, Tullio Japelli, and Luigi Pistaferri for making their SHIW constructed variables available to us, and Juan Jimeno for help with locating unemployment data. We are grateful to Olmo Silva and Mayte Trenado for their research assistance. We also thank CESifo and EUI for hosting the author team during research visits.
} 


\section{Introduction}

The age at which children leave the parental home differs considerably across countries. In 2002 coresidence rates for men aged 25 to 29 years old ranged from 20 to $22 \%$ in France, the Netherlands, and the UK. On the opposite end, in Italy it was as high as 73\%. Close to the Italian record are other southern European countries like Greece (70\%), Spain (67\%), and Portugal (58\%), but also a Nordic country like Finland (73\%). Moreover, in the mid-1980s coresidence rates for that population group were around $50 \%$ in Italy, Greece, and Spain, and 38\% in Portugal. Thus, there has been a sustained upward trend in these countries, with more stability in the remaining European Union (EU) countries.

The average emancipation age is well worth studying. To start with, it is negatively correlated with the interregional migration rate. This is around $0.5 \%$ in Italy, Portugal, or Spain, but between 1 and 2\% in other OECD countries (OECD, 2000). Lower mobility entails higher equilibrium unemployment (Layard et al., 1991). It also induces lower flexibility in responding to idiosyncratic regional shocks. Blanchard and Katz (1992) showed that high internal migration makes unemployment rate disparities across states to be scarcely persistent in the US, while they are very persistent in low internal migration countries like Italy and Spain (Decressin and Fatás, 1995, and Bentolila and Jimeno, 1998, respectively).

With a longer-term perspective, the emancipation age is also strongly related to fertility. In southern Europe young people most often leave home when they get married and, as noted by Giuliano (2004), these countries feature a very low incidence of outof-wedlock births, e.g. $3 \%$ in Greece or $8 \%$ in Italy, vis-à-vis $37 \%$ in France or $54 \%$ in Sweden. Thus, household formation and procreation are being postponed. Indeed, total fertility rates (births per woman of reproductive age) have gone down dramatically in southern Europe between 1980 and 2000: from 2.2 to 1.2 in Spain, 2.2 to 1.3 in Greece, 2.2 to 1.5 in Portugal, and 1.6 to 1.2 in Italy. In contrast, other EU countries (bar Ireland), show stability or small declines in fertility over that period (World Bank World Tables, www.worldbank.org). 
Low fertility has a crucial impact on many magnitudes. It may be good: helping growth in less developed countries or alleviating congestion. But it may also cause problems. To take a prominent example, it hampers the sustainability of pension systems. By 2030, public pension payments are forecasted to reach $20.3 \%$ of GDP in Italy, $14.1 \%$ in Spain, and $13 \%$ in Portugal. These shares imply unsustainable paths for net financial liabilities and would require increases in the tax to GDP ratio of $11.4,7.4$, and 8.2 percent, respectively, just to keep net debt constant (Disney, 2000). These figures are on the upper side of the spectrum across Europe.

In sum, there are huge disparities in coresidence rates across countries, and they matter for welfare. The economic literature on emancipation has focused mainly on parental and youth income and on housing prices (see Section 2). Here we focus on one factor which has not received much attention so far, namely the degree of job insecurity perceived by youngsters and their parents. Fogli (2004) was the first to present a model featuring low parental job insecurity as a determinant of late youth emancipation, while Becker et al. (2005) study the roles played in the child's residential decision by parental and youth income expectations. As discussed in Section 2, the theory implies that, under some conditions, ${ }^{1}$ children's job insecurity lowers the probability of moving out, while parental job insecurity raises it. These are our hypotheses of interest here.

As indicated in Section 3, an important issue is how to measure insecurity. Following a recent strand of the literature, we use subjective probabilities for job insecurity (see Manski, 2004, for a survey). To estimate its effect on coresidence, we look first at macro data. In Section 4 we document the stylized facts on coresidence and job insecurity in $12 \mathrm{EU}$ countries since the early 1980s. We show that, after controling for a host of factors, higher youth insecurity and lower parental insecurity is associated with higher coresidence. These results suggest that the rise in coresidence in the 1990s are related to the increase in the degree of job insecurity perceived by the young.

While our macroeconomic data capture youth insecurity better than parental inse-

\footnotetext{
${ }^{1}$ The conditions are a low incidence of transfers between parents and their independent children and/or a low degree of altruism (selfish parents). Regarding Italy, evidence from Guiso and Japelli (2002) suggests that the first assumption holds.
} 
curity, the opposite is true for our microeconomic data. In Section 5 we exploit the panel data structure of the Italian Survey of Household Income and Wealth (SHIW), collected by the Bank of Italy, which contains high quality data on fathers' individualspecific perceived job insecurity for 1995. The data are unfortunately not sufficiently informative to construct similar measures for children. We estimate linear probability and probit models for whether children live independently after a given year, 1995, as a function of indicators of parental job insecurity, and of a set of control variables measuring demographic, educational, and labor market characteristics of the children and their fathers. Very few papers in this literature have exploited the panel structure of microeconomic datasets; indeed most papers present just cross-sectional evidence. Our microeconometric results are consistent with the prediction that higher job security of the father deters emancipation. In Section 6 we present our conclusions.

\section{Job insecurity and coresidence}

The economic analysis of moving-out decisions has been developed by McElroy (1985), Rosenzweig and Wolpin (1993), and Ermisch (1999), among others. Standard features in this literature are: utility depends on consumption and housing, parents are altruistic but the child is selfish, individuals may exhibit a taste for privacy, and parents share income (consumption) and housing with the child when coresiding, ${ }^{2}$ and, if their income is high enough, they make transfers to the child when living apart.

It has been found that, under fairly general conditions, the higher the child's income, the higher the probability of living apart, since the child can then avoid having to share her income with her parents and also enjoy more privacy. Coresidence is more likely the higher is parental income, since then the child gets to share from a larger pie, unless parents have a strong taste for privacy -in which case they are willing to give a larger transfer to their independent child. The effect of housing prices is ambiguous. Ermisch (1999) explains this results as follows. An increase in housing prices reduces the child's utility both at home and away. If parents do not reduce their housing demand in response

\footnotetext{
${ }^{2}$ Díaz and Guilló (2005) emphasize the mother's housework as a public good.
} 
to higher prices, then utility at home is constant whereas it falls away from home, and so the child is less likely to leave. If parents' housing demand is elastic, then the decline in housing may be large enough to lead the child to leave. In the Cobb-Douglas case of a unit elasticity of substitution between housing and consumption the price of housing does not affect the coresidence decision.

Becker et al. (2005) extend the standard framework to analyze the effect on coresidence of uncertain income streams. They assume that moving out is costly. This gives rise to an option value, associated with waiting to see the realization of future income and then deciding whether to leave. Thus, a child who moved out may come to regret her decision. They show that, under general conditions, when the child's income distribution shifts to the right -in the first-order stochastic dominance sense-, the child is more likely to move out. Conversely, the same kind of shift in parental income makes coresidence more likely. ${ }^{3}$ That paper also shows that a higher variance of the child's future income holding the mean constant -i.e. under second-order stochastic dominance- makes the child more reluctant to leave. The opposite is true for the variance of parental income. ${ }^{4}$

For Anglo-Saxon countries, empirical findings confirm that higher child earnings reduce the probability of coresidence, while child unemployment raises it (Rosenzweig and Wolpin, 1993, for the US or Ermisch, 1999, for the UK). At the aggregate level, Card and Lemieux (2000) find that in regions with stronger local demand conditions and higher wages, young men are more likely to move away from their parents' homes. Results are more varied for the father's earnings: they are found to lead to more coresidence in Ermisch (1999) and in McElroy (1985), while Rosenzweig and Wolpin (1993) only estimate a significant, negative effect if parents are divorced. Housing prices are found to weakly deter emancipation in Ermisch (1999).

Regarding Southern European countries, Manacorda and Moretti (2005) emphasize the income of parents, who are portrayed as bribing their children to stay at home longer, as the source of late emancipation in Italy. They estimate an elasticity of coresidence to

\footnotetext{
${ }^{3}$ In fact, Becker et al.(2005) assume that moving out is irreversible, but show that this assumption carries no loss of generality compared to the case of finite moving costs.

${ }^{4}$ This result depends on more restrictive assumptions on the distribution of parental income, however.
} 
the father's income of 1.5 for young men. Negative effects of housing costs on emancipation are found by Giannelli and Monfardini (2003) for Italy and by Martinez-Granado and Ruiz-Castillo (2002) for Spain.

In this paper we examine a different factor, which has not been studied empirically so far, namely the degree of job insecurity perceived by youngsters and their parents. Our key variable of interest is the perceived probability of being unemployed, labeled $p$. Fogli (2004) presents a model where high parental job security induces late emancipation. Drawing from that paper, from Becker et al. (2005), and from the rest of the literature, we can infer the effect of $p$ on emancipation decisions. A higher $p$ lowers future expected income as long as income while unemployed (unemployment benefits and help from relatives or friends) is lower than earnings. ${ }^{5}$ The theory thus predicts that an increase in the child's $p$ should make emancipation less likely and an increase in the parent's $p$ should make it more likely.

Moreover, emancipation can be reversed only at a cost, which differs across families -depending, for instance, on parental preferences or the available space at home. The higher the probability that the child will be unemployed, the higher the probability that she has to return and pay the reversal cost; thus moving out will be less likely also for this reason.

Lastly, it is worth noting that in the context of Becker et al.'s (2005) model, under some conditions (e.g. unemployment income is proportional to earnings and transfers to independent children are relatively unimportant), the effect of a reduction in parental $p$ on the moving out decision directly captures the impact of a first-order stochastic dominant shift in the distribution of parental income.

\section{The measurement of job insecurity}

In empirical work, expectations are often replaced by outcomes -under rational expectations forecast errors are purely random. Recently, however, a burgeoning literature has shown the usefulness of individual expectations as measured in surveys (Manski,

\footnotetext{
${ }^{5}$ It can be shown that the effect of $p$ on the variance of income is, however, ambiguosly signed; see Guiso et al. (2002).
} 
2004). In this paper we use two different surveys to measure the perceived probability of unemployment and so it is worthwhile to briefly take stock of this literature.

Manski (1990) started the analysis of survey data on the probability of unemployment. Dominitz and Manski (1997) point out that in surveys the probability of job loss may be confounded with its subjective cost. This is the case, for example, with the question in the European Community Household Panel (ECHP) on how satisfied respondents are with their job in terms of job security (Deloffre and Rioux, 2003; Clark and Postel-Vinay, 2005). The answer set matters too. For instance, the question in the US General Society Survey on the probability of job loss features the following answers: "Very likely, fairly likely, not too likely, or not at all likely". Dominitz and Manski (1997) note that these answers are interpreted by respondents in different ways, so that they only provide ordinal information. They argue in favor of the probabilistic elicitation of expectations, as in the US Survey of Economic Expectations (SEE) question "I would like you to think about your employment prospects over the next 12 months. What do you think is the percent chance that you will lose your job during the next 12 months?".

As to their determinants, Manski and Straub (2000) found that, in the SEE, expectations of job loss tend to decrease with age and schooling, being slightly higher for women than for men and substantially higher for blacks than for whites. However, personal characteristics explain only a small part of sample variation in expectations. Green et al. (2001) examine a job-loss question in the British Household Panel Survey over 1996-97. The fear of unemployment is found to increase with age, past experience of unemployment, having a fixed-term or a part-time contract, and regional unemployment. Interestingly, the level of fear is positively correlated with actual individual unemployment experience over the subsequent year.

International comparisons are provided by Böckerman's (2004) analysis of the question "Do you worry about the security of your present work?" in a 1998 survey covering 15 European countries. This question should capture the anticipated utility implications of unemployment. He finds, surprisingly, that individuals on temporary jobs perceive lower job insecurity; perhaps because they expect to find another job easily. He also finds large differences across countries and argues that perceived insecurity is correlated 
positively with the stringency of employment protection legislation and negatively with the generosity of unemployment benefits. Clark and Postel-Vinay (2005) find the same correlations with the ECHP data on job satisfaction.

Regarding trends, the OECD (1997) claimed that there was a widespread increase in perceived job insecurity between the 1980s and the 1990s in OECD countries. In the aggregate data for the EU used in the next section we shall see that there is also an indication of increasing insecurity from the early to the late 1990s.

\section{Macroeconomic evidence for the EU}

In this section we test the hypotheses that higher own insecurity delays emancipation, whereas higher parental insecurity hastens it. We first describe the macroeconomic data used and then present and discuss the empirical results.

\subsection{Data description}

We measure coresidence through the aggregate fractions of men and women, aged 20-24 and 25-29 years old, who live at the parental home. For this purpose, data from the European Labor Force Survey is at hand for most EU countries in 1983-2002.

Data availability for perceived job insecurity is more limited. We construct it from the European Commission's Eurobarometer, which included the following questions:

1983 and 1984: "During the last year, have you (or someone in your household) worried about losing a job or not finding a job? - a lot*, a little, not at all.

1992: "And in the future, how great a risk do you think there is that you will become unemployed?" - no risk, quite a low risk, quite a high risk*, a very high risk*.

1997: "How likely do you think it is that you may lose your job in the next few years?"0\%, no risk at all; 25\%, low risk; 50\%, fifty-fifty*; 75\%, high risk*; 100\%, definitely will*.

Since the questions do not coincide in all surveys we transform the set of individual responses into a 0-1 dummy variable for not being insecure vs. being insecure, with 
the asterisks above marking the answers considered as 1 . We then compute the ageand gender-specific fractions of individuals who report being insecure. The data from the 1980s is available only for France, Germany, Italy, and the UK, while it is at hand for 12 countries in the 1990s. We also compute perceived job insecurity for people aged 50-59 years old, who are representative of parents. Note that the 1983-84 questions confound the probability with the costs of job loss, while the 1992-97 questions ask about the probability alone. They are also less clean, in that they include other household members. We shall see below that this makes a difference for the impact of insecurity on coresidence.

Table 1 summarizes the data for those four years (the Appendix gives details on definitions and sources). The overall coresidence rate is below $50 \%$. It falls with age and it is lower for women. Given the reduced number of countries observed in the 1980s, in the country breakdown of Panel C we only show data for 1992 and 1997. Coresidence is higher in Mediterranean, predominantly Catholic countries -Italy, Greece, Portugal, and Spain- and in Finland, than elsewhere. ${ }^{6}$ Over the full period, coresidence increases for both groups in the above five countries, as well as in France; Belgium and the Netherlands feature mild upward trends in the 1990s; Ireland, Germany, and the UK show mild reductions among those aged 20-24, and stability in the 25-29 y.o. group.

Considering all groups in the table, job insecurity is negatively correlated with age. For young people, there are no strong differences according to gender. Across countries, young workers feel most insecure in Spain, France, Finland, and Greece, while older workers feel least insecure in Italy, Portugal, Austria, and Ireland. Thus, of the five countries with the highest coresidence rates, three also exhibit high insecurity among youth and the other two show low insecurity among older workers.

We cannot discuss long-term trends, given the limited sample of countries available for the 1980s. But it is interesting to observe that in the period 1992-1997, the coresidence rate rose from $46.6 \%$ to $51.4 \%$ and youth insecurity from $30.1 \%$ to $35.5 \%$, while older worker insecurity stayed put at $22.4 \%$. Thus, on average, increasing youth

\footnotetext{
${ }^{6}$ It is striking to find that a Nordic country like Finland is in this respect very similar to the Mediterranean countries. But note that it has the third highest youth job insecurity.
} 
insecurity has the potential for explaining the rise in coresidence in the 1990s.

\subsection{Results}

We test the hypotheses of interest with several empirical specifications. We first estimate a regression of Coresidence rates on job insecurity perceived by youth (Insecurity) and by the older age group (Insecurity 5059):

$$
\begin{aligned}
& \text { Coresidence }_{i j t}=\sum_{i=1}^{12} \beta_{0 i} \text { Country }_{i}+\beta_{1} \text { Age } 2529+\beta_{2} \text { Female }+\beta_{3} 1984+\beta_{4} 1992 \\
& +\beta_{5} 1997+\beta_{6} \text { Insecurity }_{i j t}+\beta_{7} \text { Insecurity } 5059_{i t}+e_{i j t}
\end{aligned}
$$

where $i$ denotes countries, $j$ age-gender cells, and $t=1983,1984,1992,1997$. Country denotes a full set of country effects; Age 2529 and Female are dummy variables for those groups; 1984, 1992, and 1997 are year dummies; and $e_{i j t}$ is random noise. We report standard errors with clustering for age-gender-country cells.

Estimation results for this coresidence equation are shown in Table 2. The age- and gender-specific dummies confirm that coresidence is lower for the 25-29 year olds and for females, while the year dummies indicate an upward trend in the 1990s.

The country dummies (not shown) also confirm the cross-country differences in Table 1: Finland, Greece, Italy, Portugal, and Spain show a significantly higher rate, around $4 \%$, than the other countries, while the Netherlands has a $4 \%$ lower rate. These dummies are important, as they control for factors other than job insecurity affecting coresidence. In particular, they capture cross-country cultural differences, i.e. in preferences about coresidence -importance of family ties, attitudes regarding partnership formation, taste for independence, etc. In fact, Giuliano (2004) finds for 1994-2000 that second-generation immigrants in the US, aged 18-33, whose parents came from Italy, Greece, and Portugal are more likely to coreside than those from other countries, while those with UK origin were less likely to coreside. These differences are identified as arising from culture by the finding that only immigrants with a background from the first three countries plus Spain experienced a significant increase in coresidence after the "sexual revolution" of the late 1960s reduced the privacy cost for youth from coresiding. Similarly, Algan and 
Cahuc (2005) find that national attitudes regarding the roles of women, youngsters, and older people in the family affect employment rates in a panel of OECD countries.

Column (1) of Table 2 reveals that youth job insecurity significantly raises coresidence, while the job insecurity of the older group lowers it. A 10 percentage-point increase in the fraction of youths who perceive their job to be insecure is associated, ceteris paribus, with an increase in the coresidence rate of 1.3 points, while for the insecurity of workers in their 50s the effect is a reduction of 1.7 points.

In a second specification we try to improve the identification of economic effects, by replacing the year dummies by the (log) national real GDP per capita (at purchasing power parity). To the extent that it captures the current income of the parents, we expect a positive coefficient. This is confirmed in Column (2) of Table 2. At the sample mean of coresidence, the estimated elasticity of GDP per capita is 0.4 . The country dummies retain similar coefficients as in the first specification and their significance. Now the effect on coresidence of a 10 percentage-point increase in either insecurity variable is equal to about 1.6 points.

As previously indicated, the questions on job insecurity differ across surveys. To check whether this matters, we interact the insecurity measures with a dummy variable for 1983-84. Column (3) of Table 2 shows that coefficients are quite stable, though the elasticity with respect to GDP per capita falls to 0.31 . The response to both perceived job insecurity measures in the 1990s, around 18 percentage points in absolute value, is stronger than in the $1980 \mathrm{~s}$, where we find 3.4 points for youth insecurity and -5.1 points for parental insecurity (though the latter interaction is not significant). We might have expected that worrying about losing one's job would trigger a stronger response than the perceived risk of the event. However, the latter may be much more informative on expectations: as Manski and Straub (2000) point out, there is much more individual heterogeneity in the interpretation of stating that, e.g., one worries "a little" about losing a job (as in the 1983 question) than of stating that the chance of losing a job is 25\% (as in the 1997 question).

With the estimates for the 1990s, if the percentage of youth feeling insecure went from 0 to 100, the coresidence rate would increase by 18 percentage points, and the same 
change in the share of insecure older workers would reduce coresidence by 19 points. These are large changes, given that the average rate is $46 \%$. Alternatively, the inclusion of the two job insecurity variables reduces the standard deviation of the country dummy coefficients by $7 \%$, i.e. it explains part of the variation across countries.

Let us show how perceived insecurity can help explain the high coresidence rate observed in one of the high-coresidence countries, Italy, both in the cross-section and over time. Take men aged 20-24 in 1997. 92.4\% of them lived with their parents, and the model provides an accurate prediction, $92.7 \%$. Youth insecurity was relatively high, at $37 \%$, while parental insecurity was relatively low, at $13 \%$. If these people instead had had the lowest insecurity rate of this group across countries in that year $(17.6 \%$, in Austria) and their parents the highest rate (33.6\%, in France), then the coresidence rate would have been 6.4 percentage points lower, $86 \%$, ceteris paribus. Now take the change over time. In 1992 the youth insecurity rate was almost 30 points lower than in 1997; at the same time parental insecurity was also 9 points lower. If both insecurity rates in 1997 had been as in 1992, the coresidence rate would have been $88.9 \%$ in the later year, i.e. 3.8 points lower than the observed one. These results imply that coresidence is relatively high in Italy in part because parents are very secure in their jobs and that the recent increase is related to a rise in youth insecurity, in spite of the increase in parental insecurity.

\subsection{Robustness checks}

We end by briefly describing a couple of extensions that we tried. In the preceding specifications, differences in housing costs are captured by the country dummies. We have access to national house price indices from the Bank for International Settlements, but due to heterogeneity in definitions they are not comparable across countries. For this reason we included inflation, rather than house price levels, in the equation. The data set is reduced to 9 countries and 84 observations. The estimated coefficient on house price inflation was not significant and it changed sign depending on the specification. Although in line with the ambiguity of theoretical predictions, this result is likely to be affected by measurement error. 
Lastly, we also examined the relationship between coresidence and unemployment. As in other data sets (Böckerman, 2004), in our sample the correlation between perceived job insecurity and the unemployment rate is far from perfect, 0.5 for young workers and 0.46 for older ones. Table 3 presents the means of coresidence and unemployment for annual data in 1984-1997. At first pass, unemployment appears to be less correlated with coresidence than perceived insecurity. Unemployment rates are higher the younger the worker, as is the case for perceived insecurity. But women, who coreside less than men, show higher unemployment rates, whereas there is little difference in perceived insecurity across gender groups. More formally, we estimated the coresidence equation replacing the insecurity variables by the one-year ahead changes in the youth unemployment rates and in the 50-59 y.o. unemployment rate. These variables correspond better to the question on job loss expectations than the levels. The two variables have the expected signs -positive and negative, respectively- but their significance is low (with $p$-values around 0.1 ). The fact that perceived insecurity is more strongly related to coresidence than unemployment suggests that it encompasses a wider phenomenon than actual unemployment. Job insecurity depends, among other things, on labor market regulations, especially those on dismissals: employment protection legislation (EPL) and regulations on fixed-term contracts.

This finding brings us back to the job insecurity trends in the 1990s. We previously mentioned that Clark and Postel-Vinay (2005) obtain a negative correlation between satisfaction with a job in terms of security in the ECHP and the stringency of EPL across countries. This is not so surprising once we realize that while it reduces the probability of dismissals, EPL also reduces hiring. Job satisfaction measures could easily capture this effect. In any event, these authors do find that individual workers in permanent jobs feel more secure than those in temporary jobs. In the 1990s the fraction of fixed-term employment rose in all the countries in our sample, on average from $12.3 \%$ in 1992 to $13.5 \%$ in 1997 . Since fixed-term jobs are mostly held by young workers, it seems natural to conclude that the increasing job insecurity perceived by the young is related to the extension of fixed-term contracts. This is however not a foregone conclusion since the increase in temporary jobs is likely to lead to lower youth unemployment, and so the 
effect on perceived job insecurity remains ambiguous (but unfortunately we cannot test it due to data limitations).

In sum, the aggregate evidence for European countries we have uncovered indicates that, once persistent cross-country differences have been controlled for, job insecurity of parents and children influence the coresidence choices of European youth. This allows us to account for both differences in coresidence rates across European countries and also for the increasing trends in coresidence in the 1990s.

\section{Microeconomic evidence for Italy}

In this section we extend the macro evidence just presented with micro evidence based on the estimation of the extent to which job insecurity of fathers affects the decision of children to leave home in Italy in the second half of the 1990s.

\subsection{Data and sample design}

We use a representative sample of Italian individuals of working age, between 18 and 35 y.o., and living with their parents. This sample has been extracted from the Italian Survey of Household Income and Wealth (SHIW). We use the 1995 wave of this survey, which contains information on 8135 households and 23924 individuals, to select our baseline sample. We then use the 1998 wave to obtain information on whether a child has left home between 1995 and 1998. Our primary goal is to test whether job insecurity of the father affects this decision, controling for observable confounding factors measured in 1995. ${ }^{7}$ We cannot test whether job insecurity of the child affects her/his decision to leave home, because, as we will see, the data are unfortunately not sufficiently informative for this task.

A first reduction of the initial sample size is due to the fact that the SHIW is a rotating panel (Banca d'Italia, 1997,2000). The emancipation decision of children (the outcome) can only be observed for the 2699 out of the 8135 households that are

\footnotetext{
${ }^{7}$ We focus on job insecurity of fathers, not of both parents, because the labor participation rate of married women is low in Italy. Nevertheless, we also control for whether the mother works in our empirical analysis, in order to capture the availability of public goods such as household services.
} 
interviewed in both 1995 and 1998. Note, however, that since these panel households were randomly selected, they are still representative of the reference population. So this data limitation should only reduce the efficiency of our estimates, not their reliability.

In our empirical investigation we use a measure of perceived job insecurity, described in detail below, constructed from the answers to a survey question in which individuals are asked about the probability of having a job in the following year. This question has been designed carefully to measure various dimensions of how uncertainty is perceived and is the main reason why the 1995 wave of the SHIW is particularly useful for our purposes.

It has two problems, however. First, only individuals who are either working or unemployed are asked about their job prospects. This excludes retired "house-husbands" and students. In principle, we could have considered retired fathers as having a sort of perfectly secure job, since they are in large part individuals who enjoy perfectly safe incomes. We do not do so because retired fathers are more likely to be at home all day, and this might affect the emancipation decision of children for reasons different from the pure effect of job security. Another reason to drop households with retired fathers is that being completely sure about having no unemployment in the subsequent year is not equivalent to being sure for life because of retirement. Since we are interested in emancipation, we also restrict the sample to children aged up to 35 years old in 1995. These criteria, while required by the focus of our analysis, reduce the sample considerably, to 1142 children; note, however, that this sample is still representative of the population of children living in households where fathers are not retired in $1995 .{ }^{8}$ The characteristics of this sample are described in the first two columns of Table 4.

The second data problem related to the question on perceived uncertainty is that, to limit the length of the questionnaire, this question was not asked to labor force members in all households, but only to labor force members in households in which the head-husband was born in an odd year. ${ }^{9}$ Thus, our measure of perceived uncertainty is

\footnotetext{
${ }^{8}$ To be included in the sample, children must also be still alive, not in jail and not long-term hospitalized in 1998; these restrictions only affect a marginal number of observations.

${ }^{9} \mathrm{~A}$ different set of questions were asked in households where the father was born in even years.
} 
available only for household members belonging to the intersection between the panel subset of the SHIW and the subset in which information on job insecurity was collected.

As a result, only for 479 of the households described in the first two columns of Table 4 we observe a measure of perceived job insecurity of fathers, and only for 212 of these households we have also an analogous measure for children. It is important to note that, while the sampling design ensures that the 479 households for which paternal insecurity is available are on average observationally equivalent to the 1142 households for whom we have two years of data (see the last two columns of Table 4), this is not true for the 212 households for which the information is available for both fathers and children. The reason is that the question has not been asked to all individuals born in odd years, but to all individuals belonging to households in which the father was born in odd years. ${ }^{10}$ Because of these features of the data, we cannot use the SHIW question to build a reliable measure of job insecurity for children.

Before moving to a more detailed description of our indicators of job insecurity and children emancipation, let us note again that while data limitations force us to use a relatively small sample, this sample is still representative of the population of interest (see Table 4). Moreover, its timing structure is suitable for exploring the relationship between paternal job insecurity and the subsequent (not contemporaneous, as in most of the empirical literature) decisions of children to leave home controling for a large set of individual and family background characteristics.

\subsection{The indicator of job insecurity and the outcome variable}

The first key variable in our analysis is the reply to the following question, posed to employed and unemployed individuals: ${ }^{11}$

What are the chances that in the next 12 months you will keep your job or find one (or start a new activity)? In other words, if you were to assign a score between

\footnotetext{
${ }^{10} \mathrm{~A}$ careful reader may wonder why the information on job insecurity is available only for 479 fathers and not for $571=1142 / 2$ fathers, if it was asked to fathers born in odd years. The reason is that some fathers did not respond to the question. The comparison of observables in Table 4 clearly shows, however, that the cases of non-response are randomly distributed in the data.

${ }^{11}$ Note that those who answer "yes" to the question "Do you expect to voluntarily retire or stop working in the next 12 months?" are not asked this question.
} 
0 and 100 to the chance of keeping your job or of finding one (or of starting a new activity), what score would you assign? ("0" if you are certain not to work, "100" if you are certain to work). [A graphic scale going from 0 to 100 is shown to the respondent.]

In this paper, we use the complementary probability, namely, that of unemployment. Note that this question aims at eliciting the probability of job loss, not its costs.

As described in Guiso et al. (2002), the full sample of individuals who were asked this question in 1995 contains 4799 individuals, which become 4205 after non-respondents are excluded. Note also that those who expected to voluntarily retire or drop from the labor force are excluded. Their answers attest to the high degree of job security enjoyed by workers in Italy: the 4th decile is zero, the median is $30 \%$, a $50 \%$ chance of unemployment is reached only in the 8th decile, and only $3 \%$ of individuals are certain to be unemployed in the year following the interview. ${ }^{12}$ The authors also compare this source, restricting the sample to those employed, with the above-mentioned Survey of Economic Expectations. While in Italy $59 \%$ of individuals report a zero chance of unemployment, in the US only $31 \%$ do so. The cumulated fraction of respondents for each probability of unemployment is systematically lower in the US than in Italy up to a $10 \%$ probability (at the 7 th decile), after which it becomes similar.

Table 5 reports the distribution of the perceived insecurity indicator for fathers in our sample of 479 households. As expected given the sample design, our sample is not very different from the full sample used by Guiso et al. (2002). In our case, the average perceived unemployment probability of fathers is slightly smaller (20\% vis-à-vis 22\%) but this makes sense, since in our sample individuals are older (they must have a child of working age) and the perceived probability of unemployment drops with age.

It could be argued that, for the purposes of our analysis, such an indicator of perceived insecurity is endogenous and less informative than measures of local unemployment by age. We think that neither claim is correct, for the following reasons. First, for fathers, it is unlikely that the subjective perception of the likelihood of being employed

\footnotetext{
${ }^{12}$ The authors point out that it is not clear if employed respondents report only involuntary job losses or any change in employment status (including job mobility).
} 
in the future reflects a labor supply decision. ${ }^{13}$ In other words it is unlikely that it might capture a situation in which the father has decided not to work and thus expects not to have a job. Moreover, it does not seem plausible, given the observed very high participation rates for fathers, that they would stop working in order to make their children leave home. Thus, the expectation of future unemployment by fathers is likely to be due to a perceived truly exogenous shock more than to an increase in the preference for leisure, and can therefore be considered exogenous for the purposes of our analysis.

As for the second claim, in the case of fathers, who are typically characterized by employment rates which are very high and constant across provinces and age groups, it is most likely that a subjective measure of job insecurity is better than local unemployment as an indicator of the individual-specific degree of insecurity faced by prime-age males.

Finally, as far as the outcome variable is concerned, it is a dummy variable taking the value 1 if the child left the household between 1995 and 1998 and it is described in the last row of Table 4. In our sample of children living with their parents in 1995, only $4 \%$ decided to leave home over the following three years. When matched with the 1995 wave, the 1998 wave of the SHIW features an apparently low moving out rate. Preceding waves had larger panel-sample rates: 14\% from 1991 to 1993 and 8\% from 1993 to 1995 . But this is consistent with the aggregate Italian data: the coresidence rate for people aged 20-29 -which represent $75 \%$ of our sample- rose by 2.9 percentage points from 1991 to 1995 and by another 2 points from 1995 to 1998.

\subsection{Results}

The first two columns of Table 6 report OLS estimates based on a linear probability model of the effect of paternal job insecurity on the probability that children leave home within three years from the baseline. ${ }^{14}$ As explained above, our data are not sufficiently informative to measure children's job insecurity and to test its effect on emancipation decisions.

Ideally, we would like to base our estimates on a comparison of children who are

\footnotetext{
${ }^{13}$ Note that such a claim would instead be more plausible for children.

${ }^{14}$ Probit estimates, not included to save space, deliver qualitatively similar results.
} 
identical with respect to all relevant personal and family characteristics potentially affecting the outcome in order to identify convincingly the effect of job insecurity. We try to approximate this ideal condition by controling for a large set of variables dated in 1995, when all children are observed coresiding.

Emancipation decisions are likely to be affected by both family traits and the current situation in the household. Thus, we condition on the father's age and completed years of schooling. Note that, to the extent that father's age and schooling control for the father's income level when employed, and since unemployment benefits are proportional to previous wages in Italy, perceived job insecurity is measuring (the complement of) the probability that the father will get his full wage, as opposed to the corresponding unemployment benefits. It is worth noting that for this two-point support distribution of parental income (wages versus unemployment benefits), a reduction in perceived job insecurity exactly captures the notion of first-order stochastic dominance used in the model of Becker et al.(2005).

We also control for family wealth, home-ownership (owner-occupied $=1$ ), number of children in the household, employment status of the mother and rental prices at the province level. ${ }^{15}$ Local conditions are further controlled by the inclusion of five geographical area dummies and by the local unemployment rate in the child's agegender-province cell.

As far as children characteristics are concerned, in column (1) we control for age and gender and not for schooling. This is because the child's schooling is likely to be endogenous with respect to the child's residential choice, and so our preferred regression excludes it. However, in column (2) we include this variable on the grounds that it allows us to control in part for the child's expectations concerning her future income. Note that these expectations are also partially captured by the local controls mentioned above.

Independently of the inclusion of the child's schooling, both estimates in the first row of Table 6 indicate the same positive effect of the father's perceived insecurity on the

\footnotetext{
${ }^{15}$ We also tried including a dummy capturing whether the household owned a second house, but it was not significant.
} 
probability of the child's emancipation: if the job insecurity perceived by the father goes from zero (sure to be employed next year) to 1 (sure to be unemployed), the probability that the child leaves home increases by 9.3 percentage points. Despite the small sample size, this estimate is significantly different from zero and quite large given that the average probability of emancipation in the sample is $4 \%{ }^{16}$

As for other relevant variables, the probability of child's emancipation is negatively affected by the father's education and increases with family wealth. Older children are more likely to emancipate but we do not find significant differences by gender.

We conclude that, as far as paternal job insecurity is concerned, our hypothesis is confirmed. A child is significantly more likely to leave home when his/her father perceives that the possibility of not having a job in the future is high.

In the last two columns of Table 6 we look instead at the effect of uncertainty of future paternal income on the probability of emancipation. As discussed above, ${ }^{17}$ we conjecture that when parental income uncertainty increases the probability of moving out declines, holding expected income constant. We can say something on this conjecture because the SHIW allows us to approximate the expected earnings distribution of fathers. It asks participants the minimum, $y_{m}$, and the maximum, $y_{M}$, income they expect to earn if employed, and the probability of earning less than the midpoint of the support of the distribution, $\operatorname{Prob}\left(y \leq\left(y_{m}+y_{M}\right) / 2\right)=\pi$. Guiso et al. (2002) construct measures of income uncertainty by assuming two alternative distribution functions for earnings: uniform over the intervals $\left[y_{m},\left(y_{m}+y_{M}\right) / 2\right]$ and $\left[\left(y_{m}+y_{M}\right) / 2, y_{M}\right]$, and triangular over the same two intervals. They then assume a point expectation for unemployment income, impute it for each individual, and compute the coefficient of variation, i.e. the ratio of the standard deviation to the expected value, for each individual in their sample. We use these computations to estimate a linear probability model like the one described above,

\footnotetext{
${ }^{16}$ From a methodological point of view, it is interesting to observe that our setting is the ideal one to apply the Multiple Imputation method proposed by Rubin $(1987,1996)$ to impute perceived job insecurity to the fathers for whom this information is missing. The reason is that, by construction, the missing information is missing "completely at random", which is a crucial necessary condition for the application of Rubin's method. As expected when we use this imputation methods our results remain unchanged in terms of size of the coefficients and gain remarkably in terms of efficiency. We omit these results to save on space but they can obtained from the authors upon request.

${ }^{17}$ See also Becker et al. (2005).
} 
in which we replace job insecurity with the coefficient of variation of future expected income of the father.

Independently of the distributional assumption, in columns (3) and (4) of Table 6 we obtain positive, large and significant estimates of the effect of uncertainty on the probability that the child leaves the paternal home. If the standard deviation increases from zero to half the level of the mean, the probability of emancipation increases by 4.25 percentage points, which is again a large effect given that the average probability of emancipation in the sample is $4 \%$. These estimates provide favorable evidence for the prediction that children will tend to move out more often when their father's income is perceived as being more uncertain. ${ }^{18}$

\section{Conclusions}

In this paper, we have explored one determinant of the youth's decision to leave the parental home. Our key insight is that this decision may depend on the degree of job insecurity experienced by parents and children. Specifically, we have tested the conjecture that higher own insecurity induces children to leave the parental home later, while higher expected parental insecurity has the opposite effect.

The aggregate evidence for 12 European Union member countries in the 1980s and 1990s on coresidence rates and perceived job insecurity is consistent with these hypotheses. According to our estimates for the 1990s, for every 10 percentage-point rise in the percentage of youths feeling that their job is insecure the coresidence rate increases by 1.8 percentage points, while the same increment for workers aged 50-59 reduces coresidence by 1.9 percentage points. We read this evidence as indicating that job insecurity is a relevant explanatory variable of coresidence decisions across countries, once differences in institutions and culture are adequately controlled for. The model implies, for instance, that the high Italian coresidence rate is the result of high parental job security and, lately, of rising youth insecurity.

We have been further able to validate the hypothesis that paternal job insecurity

\footnotetext{
${ }^{18}$ Also in this case probit estimates, omitted to save space, deliver qualitatively similar results.
} 
matters using microeconomic panel data from the Italian Survey of Household Income and Wealth, collected by the Bank of Italy. Unfortunately this data set does not contain reliable measures of children's insecurity, and thus we could not use these data to validate the second part of our hypothesis. Our empirical results indicate that the likelihood that young Italians aged 18 to 35 left the parental home between 1995 and 1998 is positively related to parental job insecurity, measured in terms of their father's own perception of his chances of having a job over the subsequent 12 months. Going from a perception of a fully secure job to one of a certain job loss (or of the inability to find a new job) raises the likelihood of the child leaving by almost 10 percentage points. This is a substantial increase given that the average probability of emancipation observed in the sample is 4\%. Moreover, we find parallel evidence suggesting that children will tend to move out more often when their father's income is perceived as being more uncertain.

What are the policy implications of our analysis? Having established the quantitative importance of the effects of perceived job security on coresidence, and given that labor market institutions are important determinants of the relative job insecurity of parents and children, our results uncover a significant link between labor market institutions and family demographics. Employment protection legislation usually protects older workers vis-à-vis young ones, raising job security for the former and reducing it for the latter. Thus, our results imply that young people will emancipate later.

The main direct effects of late youth emancipation are low geographical mobility, reducing an economy's capacity to react to idiosyncratic regional shocks, and low fertility, already putting in jeopardy pension systems in southern European countries. Both of these problems are constantly debated in southern European countries but we are the first to provide quantitative evidence that links them to coresidence through the effect of job security. Coresidence also has beneficial implications: society as a whole may gain from it if parents can monitor the job search activities of their children better than public employment agencies, and thus decide on the size of the provision of "unemployment benefits" within the family. While what is socially desirable as far as these outcomes are concerned is debatable, our analysis shows that the effects of job security provisions for parents and children on youth emancipation should not be disregarded. 


\section{A Appendix: Description of macroeconomic data}

Coresidence rate. Fraction of population living at parental home. Source: European Labour Force Survey. Countries: all in the EU-15. Years: 1983-1997, though data start later for new EU members.

Perceived job insecurity. 0-1 dummy variable constructed from answers to questions asked in the Eurobarometers 19 (1983), 20 (1984), 37.1 (1992) and 47.1 (1997). (see the text for wording of questions). Data are available for the following countries. 1983 and 1984: West Germany, France, Italy, and United Kingdom. Belgium and Ireland had missing values and had to be excluded. 1992 and 1997: Belgium, Western Germany, Greece, Spain, France, Ireland, Italy, Netherlands, Austria, Portugal, Finland, and United Kingdom. Data on Luxembourg were excluded because several cells showed zero insecurity, due to the small number of observations included in the cells. We construct the job insecurity variable from 16483 individual observations for: 4 countries in 1983 and 1984 (3237 and 3197 observations, respectively) and 12 countries in 1992 and 1997 (4982 and 5067 observations, respectively). They are constructed for cells by gender, age group (20-24, 25-29, and 50-59 years old), country, and year. To construct the cells, each individual observation is weighted by its population weight as given by the survey. We end up with 120 observations (16, 16, 40, and 48, for the four years, respectively).

Real GDP per capita. Measured in 1996 US dollars at purchasing power parity. Source: Alan Heston, Robert Summers and Bettina Aten, Penn World Table Version 6.1, Center for International Comparisons at the University of Pennsylvania (CICUP), October 2002 (pwt.econ.upenn.edu). For West(ern) Germany the source is: Groningen Growth and Development Centre and The Conference Board, Total Economy Database, February 2004 (www.ggdc.net), rescaled to 1996 as the base year.

Real house prices. House price index deflated by Consumer Price index. Source: Bank for International Settlements Data Bank, national sources. Available for Belgium, Finland, France, Germany, Ireland, Italy, the Netherlands, Spain, and the United Kingdom. Years: 1983-1997.

Unemployment rate. Organisation for Economic Cooperation and Development, Corporate Data Environment, Labour Market Statistics (www1.oecd.org/scripts/cde). Data for the Netherlands in 1983-1986 were completed using International Labour Office, LABORSTA Internet, Yearly Data (laborsta.ilo.org). 


\section{References}

Algan, Y. and P. Cahuc (2005), "The Roots of Low European Employment: Family Culture?, CEPR Discussion Paper 5169.

Banca d'Italia (1997), "I Bilanci delle Famiglie Italiane nell'anno 1995", Supplemento al Bollettino Statistico, Anno VII, Numero 14.

Banca d'Italia (2000), "I Bilanci delle Famiglie Italiane nell'anno 1998", Supplemento al Bollettino Statistico, Anno X, Numero 22.

Becker, S., S. Bentolila, A. Fernandes, and A. Ichino (2005), "Job Insecurity and Youth Emancipation: A Theoretical Approach", www.anafernandes.name/insecurityt. pdf.

Bentolila, S. and J.F. Jimeno, "Regional Unemployment Persistence (Spain, 19761994)", Labour Economics 5, 25-51.

Blanchard, O. and L. Katz (1992), "Regional Evolutions", Brookings Papers on Economic Activity, 1, 1-75.

Böckerman, P. (2004), "Perception of Job Instability in Europe", Social Indicators Research 67, 283-314.

Card, D. and T. Lemieux (2000), "Adapting to Circumstances. The Evolution of Work, School and Living Arrangements among North American Youth", in D. Blanchflower and R. Freeman (eds.), Youth Employment and Joblessness in Advanced Countries, Chicago: University of Chicago Press.

Clark, A. and F. Postel-Vinay (2005), "Job Security and Job Protection", CEPR Discussion Paper 4927.

Decressin, J. and A. Fatás (1995), "Regional Labor Market Dynamics in Europe", European Economic Review 39, 1627-1655.

Deloffre, A. and L. Rioux (2003), "Do Workers Correctly Assess their Job Security? A European Comparison", mimeo, CERC and CREST-INSEE.

Díaz, A. and M.D. Guilló (2005), "Family Ties and Labor Supply", Investigaciones Económicas 29, 289-329.

Disney, R. (2000), "Crises in Public Pension Programmes in OECD: What are the Reform Options?, Economic Journal 110, F1-F23.

Dominitz, J. and C. Manski (1997): "Perceptions of Economic Insecurity: Evidence From the Survey of Economic Expectations", Public Opinion Quarterly 61, 261287.

Ermisch, J. (1999), "Prices, Parents, and Young People's Household Formation", Journal of Urban Economics 45, 47-71. 
European Communities (1999), Demographic Statistics: Data 1995-98, Luxembourg: Office for Official Publications of the European Communities.

Eurostat (2003), Eurobarometer (europa.eu.int/comm/public_opinion).

Fogli, A. (2004), "Endogenous Labor Market Rigidities and Family Ties", mimeo, New York University.

Giannelli, G.C. and C. Monfardini (2003), "Joint Decisions on Household Membership and Human Capital Accumulation of Youths. The Role of Expected Earnings and Labour Market Rationing", Journal of Population Economics 16, 265-285.

Giuliano, P. (2004), "On the Determinants of Living Arrangements in Western Europe: Does Cultural Origin Matter?", mimeo International Monetary Fund.

Green, F., A. Dickerson, A. Carruth, and D. Campbell (2001), "An Analysis of Subjective Views of Job Insecurity", mimeo, Unversity of Kent.

Guiso, L., and T. Jappelli (2002) "Private Transfers, Borrowing Constraints and the Time of Home Ownership", Journal of Money, Credit and Banking, 34, 315-339.

Guiso, L., T. Jappelli and L. Pistaferri (2002) "An Empirical Analysis of Earnings and Employment Risk", Journal of Business and Economic Statistics 20, 241-53.

Layard, R., Nickell, S. and Jackman, R. (1991), Unemployment. Macroeconomic Performance and the Labor Market. Oxford: Oxford University Press.

Little, R.J.A. and D.B. Rubin (1987), Statistical Analysis with Missing Data, New Jersey: John Wiley \& Sons.

Manacorda M. and E. Moretti (2005), "Why Do Most Italian Youths Live With Their Parents? Intergenerational Transfers and Household Structure", Journal of the European Economic Association, forthcoming.

Manski, C.F. (2004), "Measuring Expectations", Econometrica 72, 1329-1376.

Manski, C.F. and J.D. Straub (2000), "Worker Perceptions of Job Insecurity in the Mid1990s: Evidence from the Survey of Economic Expectations", Journal of Human Resources 35, 447-79.

Martinez-Granado, M. and J. Ruiz-Castillo (2002), "The Decisions of Spanish Youth: A Cross-Section Study", Journal of Population Economics 15, 305-330.

McElroy, M.B. (1985), "The Joint Determination of Household Membership and Market Work: The Case of Young Men", Journal of Labor Economics 3, 293-316.

Organization for Economic Cooperation and Development (1997), Employment Outlook, Paris. 
Organization for Economic Cooperation and Development (2000), Employment Outlook, Paris.

Rosenzweig, M.R. and K.I. Wolpin (1993), "Intergenerational Support and the LifeCycle Incomes of Young Men and their Parents: Human Capital Investments, Coresidence, and Intergenerational Financial Transfers" Journal of Labour Economics 11, 84-112.

Rubin D.B. (1987), Multiple Imputation for Non-response in Surveys, New Jersey: John Wiley \& Sons.

Rubin D.B. (1996), "Multiple Imputation after 18 years", Journal of the American Statistical Association 91, 473-489. 
Table 1: Descriptive statistics on coresidence and perceived job insecurity. 1983, 1984, 1992 and $1997(\%)$

\begin{tabular}{|c|c|c|c|c|c|c|c|}
\hline & \multicolumn{2}{|c|}{$\begin{array}{c}\text { Coresidence } \\
\text { rate }\end{array}$} & \multicolumn{4}{|c|}{$\begin{array}{c}\text { Perceived } \\
\text { job insecurity }\end{array}$} \\
\hline & & & & & & & \\
\hline & & Avg. & s.d. & Avg. & s.d. & Avg. & s.d. \\
\hline A. All & & 46.1 & $(24.5)$ & 31.8 & $\begin{array}{l}(14.0) \\
\end{array}$ & 22.9 & $(10.1)$ \\
\hline \multicolumn{8}{|c|}{ B. Age and gender: } \\
\hline \multirow{2}{*}{ 20-24 y.o. } & Male & 71.2 & $(13.3)$ & 34.5 & $(15.7)$ & & \\
\hline & Female & 54.3 & $(17.2)$ & 33.4 & $(14.0)$ & & \\
\hline \multirow{2}{*}{ 25-29 у.о. } & Male & 37.3 & $(18.7)$ & 29.3 & $(12.0)$ & & \\
\hline & Female & 21.6 & $(14.9)$ & 29.9 & $(13.9)$ & & \\
\hline \multicolumn{8}{|l|}{ C. Country: } \\
\hline Belgium & & 38.5 & $(24.4)$ & 27.2 & $(13.7)$ & 24.7 & $(11.5)$ \\
\hline Germany & & 37.1 & $(21.0)$ & 21.7 & $(6.4)$ & 20.6 & $(3.2)$ \\
\hline Greece & & 61.2 & $(17.5)$ & 40.7 & $(10.0)$ & 25.8 & $(1.6)$ \\
\hline Spain & & 71.5 & $(19.0)$ & 51.6 & $(11.1)$ & 35.7 & $(12.8)$ \\
\hline France & & 33.9 & $(20.8)$ & 45.0 & (11.8) & 27.2 & $(6.9)$ \\
\hline Ireland & & 47.2 & $(18.0)$ & 34.4 & $(12.6)$ & 15.1 & (1.6) \\
\hline Italy & & 70.5 & $(20.0)$ & 29.2 & $(15.9)$ & 8.7 & $(4.6)$ \\
\hline Netherlands & & 30.4 & $(21.7)$ & 21.6 & $(17.1)$ & 17.5 & $(0.3)$ \\
\hline Austria & & 47.8 & $(24.3)$ & 24.8 & $(10.2)$ & 14.8 & $(0.0)$ \\
\hline Portugal & & 62.1 & $(20.4)$ & 25.0 & $(8.5)$ & 13.9 & $(2.1)$ \\
\hline U. Kingdom & & 31.3 & $(17.5)$ & 33.3 & $(12.9)$ & 36.2 & $(10.5)$ \\
\hline Finland & & 67.1 & $(18.6)$ & 42.7 & $(5.9)$ & 27.8 & $(0.0)$ \\
\hline \multicolumn{8}{|l|}{ D. Year: } \\
\hline 1983 & & 37.6 & $(23.6)$ & 30.5 & $(11.6)$ & 27.3 & $(8.7)$ \\
\hline 1984 & & 37.6 & $(23.4)$ & 26.0 & $(9.6)$ & 21.4 & $(7.7)$ \\
\hline 1992 & & 46.6 & $(24.2)$ & 30.1 & $(16.1)$ & 22.4 & $(13.6)$ \\
\hline 1997 & & 51.4 & $(24.6)$ & 35.5 & (13.4) & 22.4 & $(7.5)$ \\
\hline
\end{tabular}

Note: Coresidence rate: percentage of youth population living at parental home (Eurostat: Labor Force Survey). Perceived job insecurity: percentage of respondents who think that their job is at risk (Eurostat: Eurobarometers). Data are available for 4 countries in 1983 and 1984 and 12 countries in 1992-1997. Only 1992 and 1997 data are presented for country breakdown (Panel C). See the Appendix. 
Table 2: Coresidence and perceived job insecurity (\%)

\begin{tabular}{|c|c|c|c|c|c|c|}
\hline & \multicolumn{2}{|c|}{$\begin{array}{c}(1) \\
\text { Year } \\
\text { dummies }\end{array}$} & \multicolumn{2}{|c|}{$\begin{array}{c}(2) \\
\text { Real GDP } \\
\text { per capita }\end{array}$} & \multicolumn{2}{|c|}{$\begin{array}{c}(3) \\
\text { Interacted } \\
\text { insecurity }\end{array}$} \\
\hline & Coeff. & s. e. & Coeff. & s. e. & Coeff. & s.e. \\
\hline Age 2529 & -32.77 & $(1.12)$ & -32.63 & $(1.10)$ & -32.87 & $(1.08)$ \\
\hline Female & -16.31 & $(1.05)$ & -16.30 & $(1.05)$ & -16.39 & $(1.06)$ \\
\hline 1984 & -0.48 & $(0.63)$ & & & & \\
\hline 1992 & 3.27 & $(1.38)$ & & & & \\
\hline 1997 & 6.11 & $(1.75)$ & & & & \\
\hline Log real GDP p.c. & & & 17.25 & $(6.21)$ & 14.29 & $(9.56)$ \\
\hline Insecurity & 12.60 & $(4.85)$ & 15.68 & $(4.94)$ & 18.18 & $(5.59)$ \\
\hline Insecurity 5059 & -17.66 & $(6.37)$ & -16.27 & $(6.47)$ & -18.99 & $(7.02)$ \\
\hline \multicolumn{7}{|l|}{ Insecurity $\times$} \\
\hline Dummy 1983-84 & & & & & -14.81 & $(7.07)$ \\
\hline \multicolumn{7}{|l|}{ Insecurity $5059 \times$} \\
\hline Dummy 1983-84 & & & & & 13.90 & $(9.73)$ \\
\hline Adjusted $\mathrm{R}^{2}$ & 0.96 & & 0.96 & & 0.96 & \\
\hline No. of observations & 120 & & 120 & & 120 & \\
\hline
\end{tabular}

Note: The table reports, in percentage form, OLS estimates of the coresidence equation. The dependent variable is the coresidence rate (in \%). GDP per capita is in thousand 1996 US dollars (PPP). Descriptive statistics for the data are given in Table 1 and a description of the database is given in the Appendix. The reference cell is that of males aged 20-24 living in Belgium in 1984. Country dummies included in all regressions. 
Table 3: Descriptive statistics on coresidence and unemployment. 1984-1997 (\%)

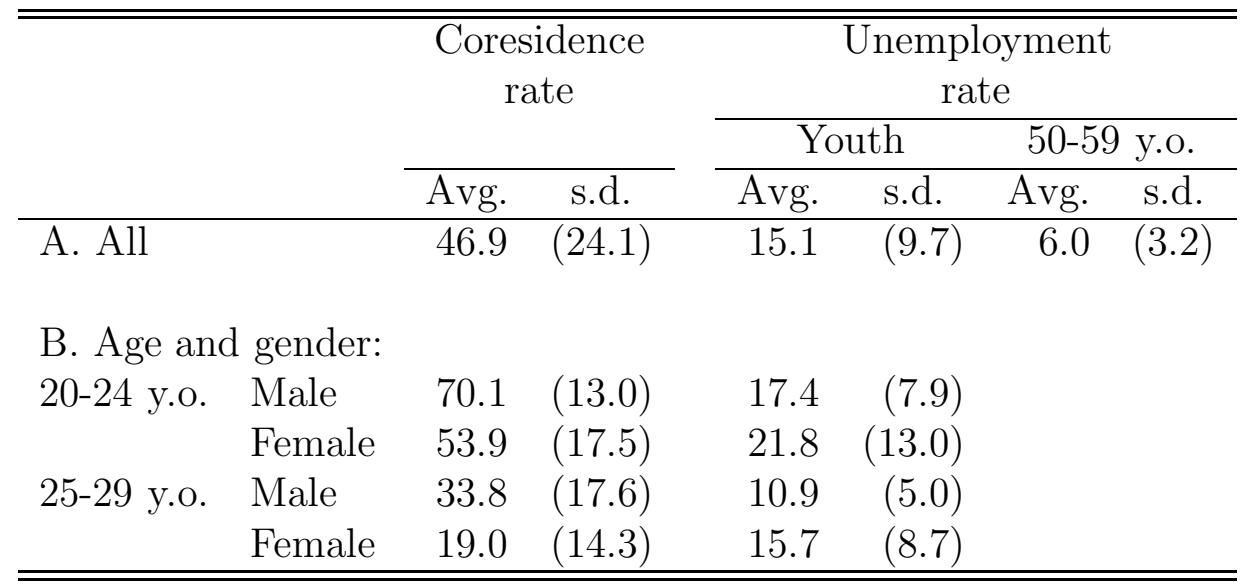

Note: Coresidence rate: percentage of youth population living at parental home (Eurostat: Labor Force Survey). Unemployment rate: Percentage of the labor force (OECD: Labour Market Statistics). The data correspond to 12 countries. See the Appendix. 
Table 4: Descriptive statistics for the sample used in the econometric analysis. 1995

\begin{tabular}{lccccc}
\hline \hline \multirow{2}{*}{ Variable } & \multicolumn{2}{c}{ Full sample } & & \multicolumn{2}{c}{ Restricted sample } \\
\cline { 2 - 3 } \cline { 5 - 6 } \cline { 5 - 6 } Age & 22.57 & 3.61 & & 22.59 & 3.54 \\
Female & 0.45 & 0.50 & & 0.44 & 0.50 \\
Homeownership & 0.71 & 0.45 & & 0.72 & 0.45 \\
Father's age & 52.23 & 5.37 & & 51.85 & 5.11 \\
Father's years of schooling & 9.24 & 4.12 & & 9.40 & 4.11 \\
Number of kids & 2.37 & 1.04 & & 2.36 & 0.87 \\
Wealth & 0.34 & 0.50 & & 0.34 & 0.55 \\
Mother employed & 0.35 & 0.48 & & 0.36 & 0.48 \\
Home rental index in province & 6.44 & 2.11 & & 6.30 & 2.19 \\
Northwest & 0.14 & 0.35 & & 0.13 & 0.33 \\
Northeast & 0.19 & 0.39 & & 0.16 & 0.37 \\
Center & 0.20 & 0.40 & & 0.17 & 0.38 \\
South & 0.36 & 0.48 & & 0.43 & 0.50 \\
Islands & 0.12 & 0.32 & & 0.11 & 0.31 \\
U rate in kid's age-gender-province cell & 0.39 & 0.23 & & 0.41 & 0.23 \\
Father's perceived job insecurity & - & - & & 0.16 & 0.28 \\
Out in 1998 & 0.04 & 0.18 & & 0.04 & 0.20 \\
\hline \hline
\end{tabular}

Descriptive statistics of variables measured in 1995 for the full sample of 1142 children who:

- live with both of their parents in 1995 ,

- belong to households interviewed in both 1995 and 1998,

- are aged between 18 and 35 years old in 1995,

- have a father who is either employed or unemployed (i.e. not retired),

- are still alive, not in jail and not long-term hospitalized in 1998,

and for the restricted sample of 479 children whose father answered the question concerning perceived uncertainty. Therefore father's perceived job insecurity is recorded only for the restricted sample. Wealth is in billions of Italian Liras. The rental index is in thousand Liras per square meter. 
Table 5: The indicator of perceived job insecurity

\begin{tabular}{ccc}
\hline \hline Value of the indicator & Percent & Cumul. \\
\hline 0.0 & 60.13 & 60.13 \\
0.1 & 11.27 & 71.40 \\
0.2 & 7.93 & 79.33 \\
0.3 & 1.88 & 81.21 \\
0.4 & 2.71 & 83.92 \\
0.5 & 4.80 & 88.73 \\
0.6 & 0.63 & 89.35 \\
0.7 & 2.09 & 91.44 \\
0.8 & 2.71 & 94.15 \\
0.9 & 1.88 & 96.03 \\
1.0 & 3.97 & 100.00 \\
\hline Total & 100.00 & \\
\hline \hline
\end{tabular}

Distribution of the indicator of job insecurity of fathers in the sample of 479 observations used in the econometric analysis (see Table 4). The indicator measures the probability assigned by the individual to the event that he does not work in the following year. 
Table 6: Paternal job insecurity and the probability of children's emancipation in Italy between 1995 and 1998

\begin{tabular}{|c|c|c|c|c|}
\hline Variable & (1) & (2) & (3) & (4) \\
\hline Father's perceived job insecurity & $\begin{array}{l}0.093^{*} \\
(0.033)\end{array}$ & $\begin{array}{l}0.093^{*} \\
(0.033)\end{array}$ & & \\
\hline Fathers's income uncertainty (uniform distr.) & & & $\begin{array}{c}0.085^{* *} \\
(0.018)\end{array}$ & \\
\hline Fathers's income uncertainty (triangular distr.) & & & & $\begin{array}{c}0.086^{* *} \\
(0.018)\end{array}$ \\
\hline Father's age & $\begin{array}{c}0.000 \\
(0.002)\end{array}$ & $\begin{array}{c}0.000 \\
(0.002)\end{array}$ & $\begin{array}{c}0.000 \\
(0.002)\end{array}$ & $\begin{array}{c}0.000 \\
(0.002)\end{array}$ \\
\hline Father's years of schooling & $\begin{array}{c}-0.005^{*} \\
(0.002)\end{array}$ & $\begin{array}{c}-0.004^{*} \\
(0.002)\end{array}$ & $\begin{array}{c}-0.004^{*} \\
(0.002)\end{array}$ & $\begin{array}{c}-0.004^{*} \\
(0.002)\end{array}$ \\
\hline Wealth & $\begin{array}{c}0.049^{* *} \\
(0.018)\end{array}$ & $\begin{array}{c}0.051^{* *} \\
(0.018)\end{array}$ & $\begin{array}{c}0.047^{* *} \\
(0.017)\end{array}$ & $\begin{array}{c}0.047^{* *} \\
(0.017)\end{array}$ \\
\hline Home-ownership & $\begin{array}{c}0.033 \\
(0.021)\end{array}$ & $\begin{array}{c}0.038 \\
(0.021)\end{array}$ & $\begin{array}{c}0.038 \\
(0.021)\end{array}$ & $\begin{array}{c}0.038 \\
(0.021)\end{array}$ \\
\hline Number of children & $\begin{array}{l}-0.017 \\
(0.011)\end{array}$ & $\begin{array}{l}-0.017 \\
(0.011)\end{array}$ & $\begin{array}{l}-0.019 \\
(0.011)\end{array}$ & $\begin{array}{l}-0.019 \\
(0.011)\end{array}$ \\
\hline Mother employed & $\begin{array}{c}-0.015 \\
(0.019)\end{array}$ & $\begin{array}{c}-0.015 \\
(0.019)\end{array}$ & $\begin{array}{c}-0.018 \\
(0.018)\end{array}$ & $\begin{array}{l}-0.018 \\
(0.018)\end{array}$ \\
\hline Home rental index in province & $\begin{array}{c}-0.009 \\
(0.005)\end{array}$ & $\begin{array}{l}-0.009 \\
(0.005)\end{array}$ & $\begin{array}{c}-0.008 \\
(0.005)\end{array}$ & $\begin{array}{l}-0.008 \\
(0.005)\end{array}$ \\
\hline Northeast & $\begin{array}{c}0.015 \\
(0.034)\end{array}$ & $\begin{array}{c}0.013 \\
(0.034)\end{array}$ & $\begin{array}{c}0.009 \\
(0.033)\end{array}$ & $\begin{array}{c}0.009 \\
(0.033)\end{array}$ \\
\hline Center & $\begin{array}{c}-0.004 \\
(0.033)\end{array}$ & $\begin{array}{c}-0.006 \\
(0.034)\end{array}$ & $\begin{array}{c}-0.007 \\
(0.033)\end{array}$ & $\begin{array}{l}-0.007 \\
(0.033)\end{array}$ \\
\hline South & $\begin{array}{c}-0.043 \\
(0.043)\end{array}$ & $\begin{array}{c}-0.049 \\
(0.043)\end{array}$ & $\begin{array}{c}-0.043 \\
(0.042)\end{array}$ & $\begin{array}{l}-0.043 \\
(0.042)\end{array}$ \\
\hline Islands & $\begin{array}{l}-0.046 \\
(0.050)\end{array}$ & $\begin{array}{l}-0.053 \\
(0.051)\end{array}$ & $\begin{array}{l}-0.047 \\
(0.050)\end{array}$ & $\begin{array}{l}-0.048 \\
(0.050)\end{array}$ \\
\hline U rate in child's age-gender-province cell & $\begin{array}{c}0.111 \\
(0.083)\end{array}$ & $\begin{array}{c}0.131 \\
(0.084)\end{array}$ & $\begin{array}{c}0.139 \\
(0.082)\end{array}$ & $\begin{array}{c}0.140 \\
(0.082)\end{array}$ \\
\hline Age & $\begin{array}{c}0.007 \\
(0.004)\end{array}$ & $\begin{array}{l}0.009^{*} \\
(0.004)\end{array}$ & $\begin{array}{l}0.008^{*} \\
(0.004)\end{array}$ & $\begin{array}{l}0.008^{*} \\
(0.004)\end{array}$ \\
\hline Female & $\begin{array}{c}0.021 \\
(0.020)\end{array}$ & $\begin{array}{c}0.022 \\
(0.020)\end{array}$ & $\begin{array}{c}0.022 \\
(0.020)\end{array}$ & $\begin{array}{c}0.022 \\
(0.020)\end{array}$ \\
\hline Years of schooling & & $\begin{array}{c}-0.005 \\
(0.003) \\
\end{array}$ & & \\
\hline R-sq & 0.077 & 0.081 & 0.106 & 0.107 \\
\hline N. obs: & 479 & 479 & 479 & 479 \\
\hline
\end{tabular}

OLS estimates based on linear probability models that include a constant term. Standard errors are reported in parentheses. Father's income uncertainty is measured by the Coefficient of Variation of the forecasted income distribution (see the text for further details). Wealth is in billions of Italian Liras. The rental index is in thousand Liras per square meter. The statistical significance of the test that the underlying coefficient is zero is denoted by: $p<$ $0.05=*, p<0.01=* *$. 